\title{
Phase-Feeding the Beef Herd for Improved Feed Utilization 1
}

Matt Hersom ${ }^{2}$

\section{Introduction}

Proper nutritional status is critical for optimal production efficiency in the beef cow herd. However, beef producers often take a "one size fits all" approach to feeding the cows in the cow herd. This singular approach to nutrient supply for the cow herd can have serious nutritional and economic ramifications. It should be obvious that not all cows have the same nutrient requirements. Nutritional requirements vary with age, breed, sex, body condition, environment, and physiologic status. By acknowledging differences in nutrient requirements that exist in the beef cow herd, management strategies can be implemented to feed beef herds to optimized feed resources and overall production.

The dairy industry utilizes the concept of differences in nutrient requirements of different cows within the herd and manages nutrient supply accordingly. In that regard, the dairy industry approaches different cow nutrient requirements by implementing phase feeding in the cow herd. Phase feeding is defined as: changing the nutrient concentrations in a series of diets formulated to meet an animal's nutrient requirements more precisely at a particular stage of growth or production. Phase feeding in the dairy industry is implemented based on placing cows into multiple feeding groups based on their lactation status. The phase feeding strategy is utilized to address the different nutrient requirements associated with milk production intensity. The dairy industry addresses the nutrient requirements of cows not on a singular basis but on a multiple nutrient basis. These nutrients include net energy (NE), degradable intake protein, undegradable intake protein, crude protein $(\mathrm{CP})$, fiber fractions and multiple minerals. By comparison, net energy of maintenance $\left(\mathrm{NE}_{\mathrm{m}}\right)$ and metabolizable protein (MP), or TDN and $\mathrm{CP}$ nutrient evaluation may be sufficient as a starting point for the beef herd because the beef cows lower production intensity compared to dairy cows.

Accurate supply of nutrients to cattle can have several positive outcomes. Providing the required nutrients can increase the production potential, reduce feed cost, and improve nutrient utilization thereby also reducing nutrient waste and decreasing environmental concerns. In some instances additional management input will be required, in others shifting management resources is all that is required. The cow herd's feed requirements amount to $54-75 \%$ of the

1. This document is AN157, one of a series of the Animal Science Department, Florida Cooperative Extension Service, Institute of Food and Agricultural Sciences, University of Florida. Original publication date October 2005. Visit the EDIS Web Site at http://edis.ifas.ufl.edu.

2. Matt Hersom, Assistant Professor, Department of Animal Sciences, University of Florida, Institute of Food and Agricultural Sciences, Cooperative Extension Service, Gainesville, FL 32611.

The Institute of Food and Agricultural Sciences (IFAS) is an Equal Opportunity Institution authorized to provide research, educational information and other services only to individuals and institutions that function with non-discrimination with respect to race, creed, color, religion, age, disability, sex, sexual orientation, marital status, national origin, political opinions or affiliations. U.S. Department of Agriculture, Cooperative Extension Service, University of Florida, IFAS, Florida A. \& M. University Cooperative Extension Program, and Boards of County Commissioners Cooperating. Larry Arrington, Dean 
annual maintenance costs for the herd (Houghton et al., 1990). Grazed forages comprise the largest and most important feedstuff for the cow, and they are the most economical feed that is available to the cow herd. Grazed forages provide the majority of the nutrients for maintaining the cow during gestation, lactation, and breeding.

\section{Differences in Beef Cattle Requirements}

The mature, non-lactating beef cow in optimal body condition score (BCS) is the reference against which other cow requirements can be evaluated. Considerable variation is often found in the amount of nutrients and quality of feed required by the cow herd. The 1996 Beef Cattle NRC does an adequate job of predicting cow nutrient requirements (Table 1). Energy and protein requirements for the mature cow vary according to state of production. Even within the mature cow's production cycle there are easily identifiable periods of different nutrient requirements. reduce feed costs by utilizing low quality feeds. At one month prior to calving, gestational requirements increase the cow's $\mathrm{NE}_{\mathrm{m}}$ and MP requirements by 50 and $47 \%$. The greatest percentage of growth of the fetal calf occurs during the final three months of gestation. Therefore, feed quality and quantity need to increase to meet the increasing nutritional requirements. At peak lactation, the mature cow's $\mathrm{NE}_{\mathrm{m}}$ requirements are 20 and $80 \%$ greater and $\mathrm{MP}$ requirements are increased 29 and $89 \%$ compared to 1 and 6 months before calving. In comparison, a 3 -year-old cow one month prior to calving has a 54 and $48 \%$ increase in $\mathrm{NE}_{\mathrm{m}}$ and MP requirements over her nutrient requirements at seven months before calving. Likewise, $\mathrm{NE}_{\mathrm{m}}$ and MP requirements increase 11 and $20 \%$ from calving to peak lactation for 3-year-old cows. Supplying sufficient quantity and quality of feed to meet the nutrient requirements of the pregnant heifer is especially critical.

Two-year-old and first calf replacement heifers have 52 and $46 \%$ increases in $\mathrm{NE}_{\mathrm{m}}$ and $\mathrm{MP}$ from their

Table 1. Daily net energy of maintenance $\left(\mathrm{NE}_{\mathrm{m}}\right)$ and metabolizable protein $(\mathrm{MP})$ requirements of cows of different ages during the production cycle.

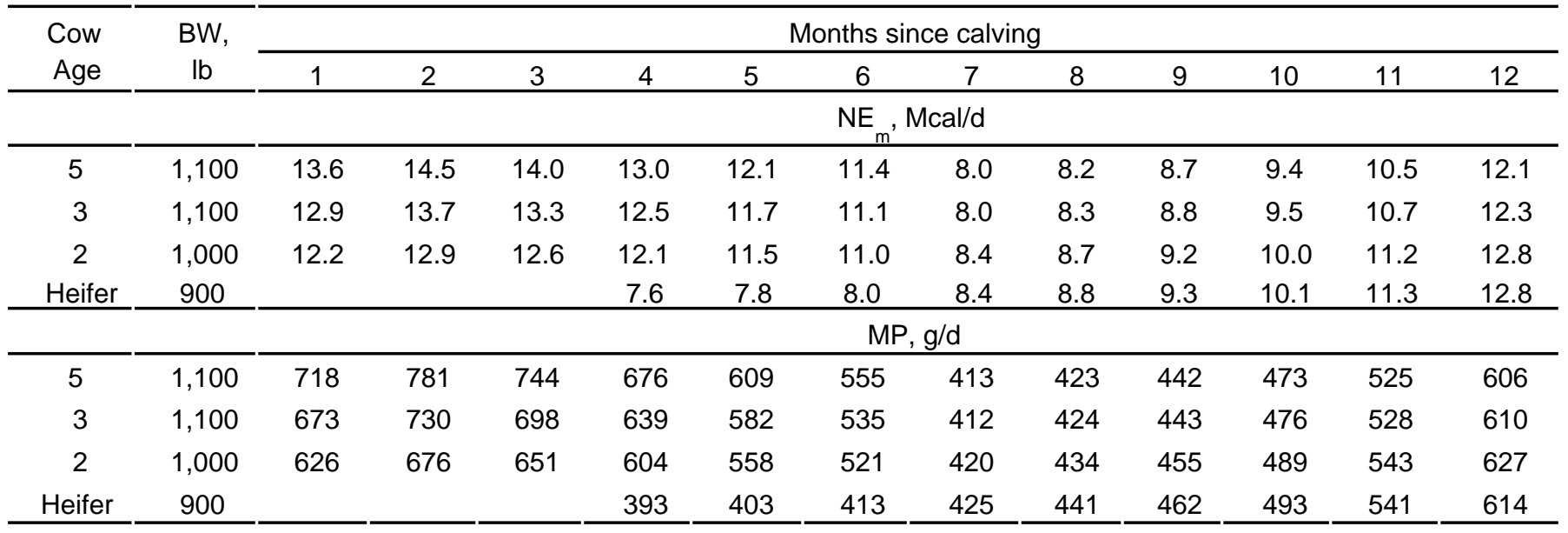

For demonstration purposes, I will use a cow that is a 5-year-old, BCS 5, with a mature body weight (BW) of $1,100 \mathrm{lb}$, and peak milk production of 16 $\mathrm{lb} / \mathrm{d}$ at 8.5 weeks after calving. The cow's nutrient requirements are only slightly above maintenance $\mathrm{NE}_{\mathrm{m}}$ and MP requirements at seven months after calving, $8 \mathrm{mcal} / \mathrm{d}$ and $413 \mathrm{~g} / \mathrm{d}$, respectively; which amounts to about $49 \%$ TDN and 7\% CP. The cow's requirements at this time are lower than at any other period in the annual production cycle. This time provides the cow-calf producer an opportunity to lowest yearly requirement to just before calving. Interestingly, the percentage change in $\mathrm{NE}_{\mathrm{m}}$ requirement from one month before calving to peak lactation is zero. The NRC assumes that the $\mathrm{NE}_{\mathrm{m}}$ requirement is already at its greatest level before calving due to requirements associated with maintenance, growth, and pregnancy. It appears that lactation only replaces the requirements associated with gestation. In reality this not likely true when one considers that requirements increase during lactation for the mature cow. In contrast, MP requirements 
change from calving to peak lactation by $9 \%$. This change is because of the same factors associated with the change in $\mathrm{NE}_{\mathrm{m}}$ requirements. The change in $\mathrm{MP}$ requirements likely more accurately reflects the increase in requirements for the first calf heifer.

When comparing nutrient requirements of cattle at different ages, physiological factors must be considered. One such consideration is dry matter intake (DMI). If one assumes the example cow can consume $2 \%$ of its BW in dry matter, DMI ranges from $22 \mathrm{lb} / \mathrm{d}$ for mature cows to $18 \mathrm{lb} / \mathrm{d}$ for $900 \mathrm{lb}$ replacement heifers (Table 2). Therefore even though absolute amounts of $\mathrm{NE}_{\mathrm{m}}$ and NP may not differ greatly, the concentration of $\mathrm{NE}_{\mathrm{m}}$ and MP in diets needs to be different for different ages of cattle to meet their requirements. Additionally, throughout the production cycle DMI capacity will vary. An additional complication occurs with the variation in DMI because of quality and quantity factors associated with forage-based diets. The $\mathrm{NE}_{\mathrm{m}}$ (mcal/d/lb DMI) and MP (g/d/lb DMI) requirements increase in all classes of cattle as they approach calving and at peak lactation. Thus, as cattle approach calving and lactation the concentration of energy and protein in their diet needs to increase to meet requirements associated with maintenance, growth, gestation, and lactation. Prior to calving, $\mathrm{NE}_{\mathrm{m}}$ requirements of five- and three-year-old cows are $15 \%$ greater than those of two-year-old cows, which are $11 \%$ greater than replacement first calf heifers. A mature cow's MP requirements prior to calving are $12-14 \%$ lower than a two-year-old cow's MP requirements, which are 12 to $9 \%$ lower than a first calf replacement heifer's.

Evidence exists for the importance of adequate cow body condition for return to estrus, improved pregnancy rate, and adequate weaning weights (Houghton et al., 1990; Sinclair et al., 1998; Wiltbank et al., 1962). Sufficient evidence in the literature recommends that cows be a minimum BCS of 5 on a 9 point scale at calving. The BCS 5 provides adequate body reserves of fat and protein for mobilization during early lactation. Moreover, mature cows that are thin prior to calving $(\mathrm{BCS}=4)$ but on an increasing plane of nutrition can reap the same benefits; improved time to estrus, improved conception rates, and improved pregnancy rates, that mature cows in adequate BCS (5) exhibit. Additional research demonstrates that cows in adequate BCS are capable of withstanding stress associated with cold and wet better than thin cows. In addition, the costs associated with achieving adequate body condition are much lower during early and mid-gestation, when cow requirements are lowest, compared with late gestation, lactation, and the breeding season. This becomes particularly important when one considers that $1 \mathrm{Mcal}$ of body energy reserves is used at $80 \%$ of what dietary energy is used to supply maintenance energy.

\section{Relevant Research Results}

The idea of phase feeding the beef cow herd may not have the prevalence that it does in the dairy industry, however there are specific research results that address many of the key issues of phase feeding. Numerous published research articles address the differences between gestation and lactation in cows, and differences between mature and young cows.

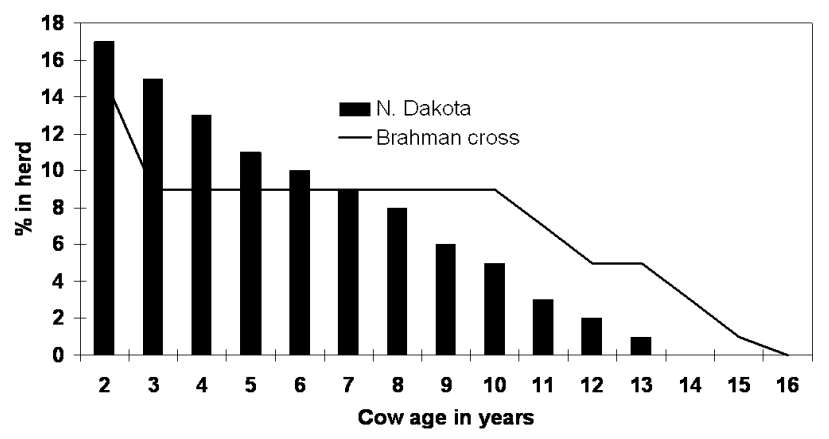

Figure 1. Cow age distribution in a herd.

One of the most likely ways to segregate the cow herd is by cow age. Differences in cow age are often translated into differences in cow BCS, DMI, milk production, reproductive performance, and ultimately nutrient requirements. Figure 1 contains data complied by North Dakota State University in which they reported the cow age distribution within a herd over 20 years. Within this herd, $17 \%$ of the cows are in the first calf heifer category, whereas $11 \%$ of the herd is 10 years old or older. There are differences in the ability of cows to perform within similar nutritional environments. Sawyer et al. (2004) examined the ability of cull cows to perform in a finishing situation. Average daily gain, DMI, and gain 
Table 2. Net energy of maintenance $\left(\mathrm{NE}_{\mathrm{m}}\right)$ and metabolizable protein $(\mathrm{MP})$ requirements per pound of dry matter intake of cows with different age during the production cycle.

\begin{tabular}{|c|c|c|c|c|c|c|c|c|c|c|c|c|c|}
\hline \multirow{2}{*}{$\begin{array}{l}\text { Cow } \\
\text { age }\end{array}$} & \multirow{2}{*}{$\begin{array}{c}\text { DMI, } \\
\mathrm{lb}\end{array}$} & \multicolumn{12}{|c|}{ Months since calving } \\
\hline & & 1 & 2 & 3 & 4 & 5 & 6 & 7 & 8 & 9 & 10 & 11 & 12 \\
\hline & & \multicolumn{12}{|c|}{$\mathrm{NE}_{\mathrm{m}}, \mathrm{Mcal} / \mathrm{lb}$ of DMI } \\
\hline 5 & 22 & 0.62 & 0.66 & 0.64 & 0.59 & 0.55 & 0.52 & 0.36 & 0.37 & 0.40 & 0.43 & 0.48 & 0.55 \\
\hline 3 & 22 & 0.59 & 0.62 & 0.61 & 0.57 & 0.53 & 0.51 & 0.36 & 0.38 & 0.40 & 0.43 & 0.49 & 0.56 \\
\hline 2 & 20 & 0.61 & 0.65 & 0.63 & 0.61 & 0.58 & 0.55 & 0.42 & 0.44 & 0.46 & 0.50 & 0.56 & 0.64 \\
\hline \multirow[t]{2}{*}{ Heifer } & 18 & & & & 0.42 & 0.43 & 0.44 & 0.47 & 0.49 & 0.52 & 0.56 & 0.63 & 0.71 \\
\hline & & \multicolumn{12}{|c|}{$\mathrm{MP}, \mathrm{g} / \mathrm{lb}$ of $\mathrm{DMI}$} \\
\hline 5 & 22 & 32.6 & 35.5 & 33.8 & 30.7 & 27.7 & 25.2 & 18.8 & 19.2 & 20.1 & 21.5 & 23.9 & 27.6 \\
\hline 3 & 22 & 30.6 & 33.2 & 31.7 & 29.1 & 26.5 & 24.3 & 18.7 & 19.3 & 20.1 & 21.6 & 24.0 & 27.7 \\
\hline 2 & 20 & 31.3 & 33.8 & 32.6 & 30.2 & 27.9 & 26.1 & 21.0 & 21.7 & 22.8 & 24.5 & 27.2 & 31.4 \\
\hline Heifer & 18 & & & & 21.8 & 22.4 & 22.9 & 23.6 & 24.5 & 25.7 & 27.4 & 30.1 & 34.1 \\
\hline
\end{tabular}

efficiency decreased linearly with increasing cow age. Decreasing DMI and gain efficiency implies that additional feeding management would be required for cattle with advancing age because of a decreasing ability to compete for and use feed. It should be noted that crossbred, especially Bos indicus x Bos taurus cattle, have generally been recognized to have a longer productive lifespan compared to non-Brahman-influenced cattle (Thrift and Thrift, 2003).

Work by Sowell et al. (2003) reported the effect of cow age on forage and liquid supplement intake. Forage DMI increased from $26 \mathrm{lb} / \mathrm{d}$ by two-year-old cows to $40 \mathrm{lb} / \mathrm{d}$ by five-year-old cows. Likewise, supplement DMI increased from 1.1 to $1.5 \mathrm{lb} / \mathrm{d}$ as cow age increased. Bowman and Sowell (1997) reported variation in cow supplement intake regardless of supplement form or delivery method. The variation in intake of supplement stems from two likely sources, the opportunity to consume supplement in competitive situations and individual animal variation in intake in non-competitive situations. Sowell et al. (2003) monitored supplement intake distribution. The greatest range in supplement intake was reported for three- and four-year-old cows (Table 3). Supplement intake variation was lowest (63\%) for four-year-old cows and greatest (98\%) for five-year-old cows. The targeted level of supplement intake was $1.1 \mathrm{lb}$ of DM/d. Fifty-four percent of the two-year-old cows consumed less than the targeted amount of supplement, whereas $42 \%$ of the three- to six-year-old cows consumed below the targeted supplement DMI. Total time of supplement consumption and feeding bouts per day were also lower for two- and three-year-old cows compared with older cows. Combined, these data indicate that the social interactions in a mixed age herd can result in lower supplement intakes by younger cows. Intake levels of supplements below that desired and formulated to meet cow nutrient requirements can have detrimental effects on young cow productivity. Management schemes that minimize the negative social interactions of boss cows with young growing cows would be advantageous.

\section{Dividing the Cow Herd}

There are several factors to consider before splitting up the cow herd to phase feed the herd as an alternative to whole-herd management. The first consideration is total cow herd size. Phase-feeding management will likely work best in herds of 100 cows or more; splitting a herd with less than 40 head will not be effective in terms of labor and equipment use (Blasi, 1995). Splitting the cow herd also requires multiple pastures, fencing, water, and likely feeding facilities (troughs, lick tanks, hay rings, etc.). In the nominal beef herd some easily identifiable groups exist: 1) dry, mature pregnant cows; 2) lactating mature cows; 3) pregnant replacement heifers; 4) weaned replacement heifers; 5) growing steers and heifers; 6) herd bulls (Gadberry, 2003). In addition, special groups of cattle such as thin cows and lactating first calf heifers have additional nutritional and management requirements. 
Table 3. Effect of cow age on performance and forage and supplement consumption.

\begin{tabular}{|c|c|c|c|c|c|c|}
\hline \multirow[b]{2}{*}{ Item } & \multicolumn{5}{|c|}{ Cow age, yr } & \multirow[b]{2}{*}{ SEM } \\
\hline & 2 & 3 & 4 & 5 & 6 & \\
\hline BW change, lb & $-46^{a}$ & $-62^{b}$ & $-73^{b}$ & $-73^{b}$ & $-62^{b}$ & 7.0 \\
\hline BCS change & -0.4 & -0.4 & -0.4 & -0.4 & -0.4 & 0.008 \\
\hline Forage DMI, lb/d & $26^{\mathrm{a}}$ & $32^{b}$ & $35^{\mathrm{c}}$ & $40^{d}$ & $36^{\mathrm{c}}$ & 1.2 \\
\hline Supplement DMI, Ib/d & 1.1 & 1.8 & 2.0 & 1.5 & 2.4 & 0.29 \\
\hline Supplement DMI range, Ib & $0-5.1$ & $0-10.3$ & $0-9.0$ & $0-6.4$ & $0-5.9$ & - \\
\hline \multicolumn{7}{|c|}{ Proportion of cows with supplement DMI below target, \% } \\
\hline & 54.4 & 43.2 & 37.2 & 46.3 & 18.8 & 9.4 \\
\hline
\end{tabular}

SEM $=$ Standard error of mean

a,b,c,d Means within a row with different superscripts differ $P<0.05$.

Not all of the previously listed five groups will exist in every herd or it may not be feasible to split the herd into that many groups. However, generally at least three groups can be made from a typical cow herd. Separation into three manageable groups will assist in matching the nutritional needs of each group.

Group 1 - Mature cows in good BCS. These cows will have lowest maintenance requirements. Mature cows can use low-quality forages and will likely require less supplementation. Herd bulls would fall in this group, but they should be managed as a separate group to maintain a defined breeding season.

Group 2 - Bred replacement heifers and second calf cows. As mentioned previously, these cows are young, still growing, and do not compete effectively for feed with mature cows. Likely, better quality forages and supplemental feeds will be required by this group to meet growth, gestation, and lactation requirements.

Group 3 - Thin and old cows. This group should include cows older than 10 years old or with a BCS less than four. As noted earlier Brahman cross cattle may be older before entering this group. These cows will need extra energy during several periods of the production cycle. This group should be the most fluid group, because as cows gain BCS or are culled because of age, cows will move out of the group.

Another additional consideration for dividing the cow herd besides age and BCS is expected calving date. As calving date approaches, cow requirements increase, thus additional nutrition may be needed. Separating by calving date also provides some management advantages concerning calving management. As a practical point, weaning a calf is often the easiest way to manipulate a post-partum cow's nutritional requirements. The creation of different groups allows each group to use the variation in quality and quantity of feedstuffs to optimize the use of feed resources. A much more efficient and economical job can be done if the cattle are separated into feeding groups to address their nutritional requirements.

\section{Practical Application in the Beef Herd}

In order to gain the advantage that separate group or phase feeding the cow herd allows, a producer needs to match the requirements of the cows to the feedstuffs available. In a large cow herd with a wide range of individual nutrient requirements there are three basic feeding options: 1) feed all cows in the herd to the requirements of the highest in the group, in which case many cows will be overfed and feed resources wasted; 2) feed to the lowest requirements in the group, in which case many cows will be underfed and production will suffer; 3 ) feed to the average of the group requirements and a bit of all of the above will occur. The key is to allocate cows to groups so that individual cow requirements are as close as possible.

The nutritional requirements of the dry, mature, pregnant cow are only slightly above maintenance and lower compared to any time period during the production cycle. Cow nutrient requirements increase 
dramatically after calving and during lactation especially leading up to peak milk production and the rebreeding period. Milk production has a close positive relationship to nutrient requirements. Therefore, during this period feed quality and quantity should be increased.

The pregnant replacement heifer is an interesting mix; on one hand she still has nutrient requirements for both growth and pregnancy, on the other hand she is growing and her intake potential has increased so that some lower quality feed can be utilized. Additionally, as mentioned before, the replacement heifer after calving has maintenance, growth, and lactation nutrient requirements.

Weaned replacement heifers have the disadvantage of having the greatest requirements for growth while being at the bottom of the social food chain. Thus if weaned replacement heifers are fed with the mature cow herd these heifers are likely to under-consume supplemental feeds resulting in inadequate nutrient supplies to meet growth requirements in order to reach adequate $\mathrm{BW}$ for future breeding. In addition, because cows derive more total energy from their ruminal fermentation and have lower maintenance energy requirements than heifers, higher-quality diets will be required for heifers than for cows to achieve acceptable performance (Varel and Kreikemeier, 1999).

In situations in which producers are retaining ownership to increase sale weights, growing cattle should be fed separately. Because these calves have limited DMI ability relative to more mature and larger cows, more nutrient dense feedstuffs need to be used. Growing cattle most likely will need grain and protein supplementation, which more mature cows do not need, to achieve production goals.

Another consideration for pregnant replacement heifers, weaned replacement heifers, and growing animals is the source of supplemental protein. Mature cows can use non-protein nitrogen well, whereas the growing animals perform better consuming natural protein sources.

Herd bulls will be the smallest group. Depending on the bull's condition, maintenance feeding is all that is required. Bulls can use low-quality forages and non-protein nitrogen.

A practical example of the advantage of phase feeding the cow herd occurs when feeding cows of different BCS. In order to move a 1,100 lb Brangus cow from a 3 to $4 \mathrm{BCS}, 83,48$, or $42 \mathrm{lb}$ of bahiagrass hay, molasses, or soybean hulls would be required above the feed for maintenance. Similarly, to move a cow from 4 to $5 \mathrm{BC}$ requires an additional 94,55 , or $48 \mathrm{lb}$ of bahiagrass hay, molasses, or soybean hulls, respectively. In contrast, a cow with a BCS of 6 could be allowed to move to a 5 BCS and 75,44 , or $39 \mathrm{lb}$ of bahiagrass hay, molasses, or soybean hulls could be saved. In this scenario, if cows of BCS 3 and/or 4 are in the same group as BCS 6 cows, the dilemma becomes what group of cows you are feeding to meet requirements.

Decisions regarding feed resources should be made to match animal requirements with nutrients supplied by the feeds. In that regard, cows with greater requirements should be supplied with the highest quality feeds. Because beef cattle production does rely on pasture-based production for the majority of feed resources cattle producers can use this to some advantage. A grazing management system that allows different groups of cattle to use the same pasture at different times, thereby tailoring the quality of the forage to the needs of the cow, is an option. Grazing systems like lead-follow, first, second, and third grazers work to allow cattle in groups with greater requirements to have first access to the pasture forage so that they can select the forage with the greatest nutritional value.

A main consideration between the dairy industry and beef industry implementation of phase feeding is the source of the feed. In the dairy industry during much, if not all, of the production cycle the dairyman provides the feedstuff to the dairy cow. The herd's nutrition and defined group's nutritional supply can be more tightly controlled and matched to the cow's requirements. Feed inputs, production output, and efficiency of use can be measured with relative ease. However, in the beef industry, pasture-based production systems for the cow herd are the predominate production practice. Pasture and forage feedstuffs introduce unknowns in terms of nutrients 
supplied, consumed, and used. Pasture production systems also offer challenges due to seasonal variation associated with the nutrient supply.

\section{Conclusion}

There are many pasture-roughage-supplement feed options that are typically available.

Understanding the nutritional needs of the individuals within the cow herd can help to allocate feed resources. Rather than taking the "one size fits all" management practices, phase feeding can prevent over-and underfeeding of the cow herd and thus give cattle producers more flexibility to use feed resources and obtain a greater return on investment of feed resources. Optimal investment of the feed resources into the cow herd can positively influence the cows' performance. Increased cow performance through improved nutrition will result in improved economic efficiency for the beef cow enterprise.

\section{References}

Blasi, D. A. 1995. Alternative beef cow supplementation strategies. Beef Tips Dec. Kan. St. Univ. Ext. Ani. Sci. and Indust.

Bowman, J. P., and B. F. Sowell. 1997. Delivery method and supplement consumption by grazing ruminants: a review. J. Anim. Sci. 75: 543-550.

Gadberry, S. 2003. Grouping the commercial beef herd for winter feeding. Univ. Ark. Coop. Ext. Serv. FSA3033-PD-6-03RV.

Houghton, P. L., R. P. Lemenager, L. A. Horstman, K. S. Hendrix, and G. E. Moss. 1990. Effects of body composition, pre- and postpartum energy level and early weaning on reproductive performance of beef cows and preweaning calf gain. J. Anim. Sci. 68: 1438-1446.

NRC. 1996. Nutrient Requirements of Beef Cattle. $7^{\text {th }}$ rev. ed. Natl. Acad. Press, Washington DC.

Sawyer, J. E., C. P. Mathis, and B. Davis. 2004. Effects of feeding strategy and age on live animal performance, carcass characteristics, and economics of short-term feeding programs for culled beef cows. J. Anim. Sci. 82: 3646-3653.
Sinclair, K. D., S. Yildiz, G. Quintans, F. E Gebbie, and P. J. Broadbent. 1998. Annual energy intake and the metabolic and reproductive performance of beef cows differing in body size and milk potential. Anim. Sci. 66: 657-666.

Sowell, B. F., J. G. P. Bowman, E. E. Grings, and M. D. MacNeil. 2003. Liquid supplement and forage intake by range beef cows. J. Anim. Sci. 81: 294-303.

Thrift, F. A., and T. A. Thrift. 2003. Review: Longevity attributes of Bos indicus x Bos taurus crossbred cattle. Prof. Ani. Sci. 19: 329-341.

Varel, V. H., and K. K. Kreikemeire. 1999. Lowand high-quality forage utilization by heifers and mature beef cows. J. Anim. Sci. 77:2774-2780.

Wiltbank, J. N., W. W. Rowden, J. E. Ingalls, K. E. Gregory, and R. M. Koch. 1962. Effect of energy level on reproductive phenomena of mature Hereford cows. J. Anim. Sci. 21: 219-225. 